\title{
Man Chinese
}

National Cancer Institute

\section{Source}

National Cancer Institute. Man Chinese. NCI Thesaurus. Code C158161.

A Chinese person from the Man ethnic group. 